\title{
Paleobathymetry of a Silurian shelf based on brachiopod assemblages: an oxygen isotope test
}

\author{
Karem Azmy, Jan Veizer, Jisuo Jin, Paul Copper, and Uwe Brand
}

\begin{abstract}
Primary $\delta^{18} \mathrm{O}$ signals of 97 brachiopod shells from the Lower Silurian (Llandovery) carbonate succession of Anticosti Island were used to test the hypothesis of water-depth and water-temperature gradient for the Silurian onshoreoffshore benthic assemblages (BA1-BA5). The analyzed shells were from the Pentamerus palaformis, Pentamerus oblongus, Stricklandia planirostrata, Ehlersella davidsonii, and Triplesia anticostiensis communities, which have been interpreted to occupy different water depths. Screening of the shells, using petrographic and chemical criteria, confirmed good preservation of original material. Shells of P. palaformis, P. oblongus, E. davidsonii, and T. anticostiensis have very similar mean $\delta^{18} \mathrm{O}$ values (-5\%o Vienna Peedee Belemnite (VPDB)), while shells of S. planirostrata have a somewhat lighter value $(-5.6 \%)$. The $\delta^{18} \mathrm{O}$ values, in corroboration with taphonomic and paleoecologic data, suggest the following: (1) that the water mass of the Anticosti carbonate shelf was warm and well mixed vertically during the Early Silurian; (2) that the pentamerid brachiopod paleocommunities that lived at $\sim 20-90 \mathrm{~m}$ of water-depth show little $\delta^{18} \mathrm{O}$ differentiation in their shell composition; and (3) that the Pentamerus, Stricklandia, and Triplesia communities need to be investigated at the species level, as both taphonomic and oxygen isotopic data indicate that the Stricklandia planirostrata Community most likely lived in a notably warmer, shallower water than the Pentamerus palaformis Community and that Triplesia anticostiensis (BA5) lived at water temperature comparable to that of the Pentamerus habitat (BA3). This may suggest either that, at the generic level, the Pentamerus, Stricklandia, and Triplesia (Clorinda equivalent) communities may have had substantial overlap in their spatial distribution in the BA3-BA4 paleobathymetric settings or that the isotope signals are too faint to record water depth differences on a tropical shelf.
\end{abstract}

Résumé : On a utilisé les signaux $\delta^{18} \mathrm{O}$ primaires de 97 coquilles de brachiopodes (BA1-BA5) provenant de la succession carbonatée de l'île d'Anticosti (Silurien inférieur - Llandoverien), afin de vérifier l'hypothèse d'un gradient thermiqueprofondeur des assemblages benthiques de la côte - au large, au Silurien. Les coquilles analysées provenaient de communautés Pentamerus palaformis, Pentamerus oblongus, Stricklandia planirostrata, Ehlersella davidsonii et Triplesia anticostiensis, lesquelles, selon l'interprétation admise, auraient occupé des profondeurs sous-marines différentes. Le criblage des coquilles à l'aide de critères pétrographiques et chimiques a attesté la bonne préservation du matériel d'origine. On a obtenu des valeurs moyennes de $\delta^{18} \mathrm{O}$ très proches $(-5 \%$ VPDB) pour les coquilles de P. palaformis, de $P$. oblongus, de E. davidsonii et de T. anticostiensis, tandis que pour celles de S. planirostrata, la valeur obtenue était légèrement moins élevée $(-5.6 \%)$. Les valeurs de $\delta^{18} \mathrm{O}$ obtenues, corroborées par les données taphonomiques et paléoécologiques, laissent penser que (1) la masse d'eau de la plate-forme carbonatée de l'île d'Anticosti était chaude et verticalement homogène au cours du Silurien inférieur; (2) les valeurs de $\delta^{18} \mathrm{O}$ dans la composition des coquilles des paléocommunautés de brachiopodes de la famille des pentamérides ayant vécu à des profondeurs comprises entre environ $20 \mathrm{~m}$ et $90 \mathrm{~m}$ varient peu et (3) compte tenu des données taphonomiques et isotopiques de l'oxygène, qui indiquent d'une part que la communauté Stricklandia planirostrata a très probablement vécu dans des eaux moins profondes et plus chaudes que celle des Pentamerus palaformis et d'autre part que les Triplesia anticostiensis (BA5) ont vécu dans des eaux de température comparable à celle de l'habitat des Pentamerus (BA3), il s'avère nécessaire de pousser les investigations sur les communautés Pentamerus, Stricklandia et Triplesia au niveau de l'espèce. Cela pourrait signifier que, au niveau du genre, les répartitions spatiales des communautés Pentamerus, Stricklandia et Triplesia (équivalent des Clorinda) des relevés paléobathymétriques du BA3-BA4 se sont chevauchées dans une large mesure ou que les signaux isotopiques sont trop faibles pour enregistrer des différences de profondeurs d'eau sur une plate-forme tropicale.

[Traduit par la Rédaction]

Received 2 June 2005. Accepted 2 November 2005. Published on the NRC Research Press Web site at http://cjes.nrc.ca on 27 March 2006.

Paper handled by Associate Editor B. Chatterton.

K. Azmy. ${ }^{1}$ Memorial University of Newfoundland, St. John's, NL A1B 3X5, Canada.

J. Veizer. Ottawa-Carleton Geoscience Centre, University of Ottawa, ON K1N 6N5, Canada.

J. Jin. Department of Earth Sciences, The University of Western Ontario, London, ON N6A 5B7, Canada.

P. Copper. Department of Earth Sciences, Laurentian University, Sudbury, ON P3E 2C6, Canada.

U. Brand. Department of Earth Sciences, Brock University, St. Catharines, ON L2S 3A1, Canada.

${ }^{1}$ Corresponding author (e-mail: kazmy@mun.ca). 


\section{Introduction}

Advances during the last decades in the understanding of the paleoceanography of the Cenozoic times, particularly the temperature profile of oceans, were to a large degree based on studies of the variations through time of the isotopic composition of contemporaneous planktonic and benthic foraminifera (e.g., Williams et al. 1988). The situation is much less favourable for the Paleozoic because the temporal resolution is coarser, and, more importantly, there is a lack of both calcareous shells from comparable pelagic and benthic habitats. While the temporal resolution now approaches that of a biozone (Veizer et al. 1999) or better for specific profiles, rare attempts have yet been made to test the oxygen isotope gradient with depth (e.g., Adlis et al. 1988; Railsback et al. 1990; Grossman et al. 1991). Because of the habitat restrictions just mentioned, such a test must be confined to the shelf environment, with its limited depth and temperature ranges, and without any guarantee that the isotope techniques will be capable of detecting these restrictions. This contribution is, therefore, only a test of the feasibility of such an approach.

In his classic study of the Early Silurian shelly benthos of the Welsh Borderlands, Ziegler (1965) recognized a succession of progressively deeper water brachiopod communities- the Lingula, Eocoelia, Pentamerus, Stricklandia, and Clorinda communities_-which distributed in parallel zones from littoral, inner shelf, to outer shelf settings and merged into basinal graptolite shale facies. Later, the brachiopod communities were further refined by quantitative analysis of their taxonomic components (Ziegler et al. 1968). Boucot (1975) expanded the concept of five depth-related brachiopod communities into five benthic assemblages by taking into consideration a broader range of fossil groups and their limiting paleoenvironmental parameters (particularly the degree of water turbulence and substrate type). Ziegler's communities and Boucot's benthic assemblages (BAs) inspired a series of paleosynecologic studies on Phanerozoic fossil communities (McKerrow 1979; Boucot 1999). These studies have been applied to reconstruction of eustatic sea-level changes from vertical sequence of depth-related benthic communities in many parts of the world (e.g., Johnson and Campbell 1980; Johnson et al. 1981; 1985; Johnson 1987; Landing and Johnson 1998).

Despite many publications on Early Silurian brachiopod communities, there have been limited attempts to test the hypothesis of depth dependence of shelly communities. Brett et al. (1993) made a detailed examination of the criteria and constraints for determining absolute water depth of ancient communities. Ziegler's original model of community zonation was based on brachiopod assemblages from a fine-grained siliciclastic ramp setting, which typically has a relatively uniform gradient from shoreline to continental shelf break. However, carbonate shelves and platforms that were rich in coral-stromatoporoid reefs, which were characteristic of the Laurentian craton during the Silurian, most likely had a high degree of topographic heterogeneity and an irregular gradient. In such geological settings, lateral changes in water turbulence levels and substrate conditions may have occurred over short distances because of the presence of reefs. Consequently, the distribution of brachiopod communities is expected to be patchy rather than zoned parallel to the shoreline. Fossil data from Early Silurian carbonate rocks of major Canadian sedimentary basins show irregular distribution patterns of brachiopod communities, as indicated by the following features:

(1) Rapid lateral change of communities: In the reefal facies of the Attawapiskat Formation (late Llandovery) of the Hudson Bay Basin, both Pentameroides (= Pentamerus Community of Ziegler = BA3 of Boucot) and GypidulaClorinda (= BA5 of Boucot) occur in great abundance in the same stratigraphic unit, with Pentameroides somewhat more dominant in reefal facies, and GypidulaClorinda more common in back-reef to inter-reef facies (Jin et al. 1993; Jin 2005). In a single patch reef, a Pentameroides Community has been shown to pass laterally into an Eocoelia Community in the inter-reef facies within several metres (Jin 2003).

(2) Taphonomic evidence: In the Jupiter Formation (middle Aeronian to middle Telychian) of Anticosti Island, numerous shells beds of Pentamerus and stricklandiid, as well as some Triplesia shells, are present. The degree of anterior shell damage (most likely caused by storm events) in the Pentamerus and the stricklandiid communities varies from completely broken and (or) truncated shells to the near-perfect preservation of shells. In particular, Pentamerus palaformis-dominated brachiopod assemblages in the Goeland Member of lower Jupiter Formation are usually characterized by well-preserved Pentamerus shells with little damage, whereas Pentamerus oblongusdominated assemblages in the upper Pavillon Member near the top of the Jupiter Formation are usually characterized by disarticulated or broken shells (Jin and Copper 2000). A similar range of shell preservation can be found in stricklandiid brachiopod assemblages that are dominated by various species of Stricklandia, Microcardinalia, or Ehlersella. In general, well-preserved complete shells are much more common in Pentamerus palaformis beds than in the stricklandiid beds, but the opposite is true when Pentamerus oblongus beds are compared with stricklandiid beds. As Pentamerus and stricklandiids have similar shell sizes and structures, the degree of shell damage is considered to reflect the water depth and turbulence level (in relation to various storm wave bases) of the brachiopod habitat. This implies that the two species of Pentamerus from Anticosti Island must have covered a much wider range of water-depth conditions than the BA3 settings usually assigned. A similar range of taphonomic variation in Pentamerus shell beds has been observed also by Johnson (1989) in his study of the Pentamerus-rich tempestites of southern Norway. It is, therefore, essential to test the discrepancies between the Laurentian fossil data and the hypothesis of depthrelated communities.

Calcitic brachiopods precipitate shells of low-Mg calcite mostly in, or close to, isotopic equilibrium with ambient seawater, except for few species (Carpenter and Lohmann 1995; Brand et al. 2003; Auclair et al. 2003). Low-Mg calcite is a relatively stable phase which resists diagenesis and usually retains the primary chemical and isotope signals. Petrographic and chemical techniques, such as petrographic microscopy, cathodoluminescence, scanning electron microscopy (SEM), and trace-element analysis were shown to be effective tools 
for evaluation of diagenetic alteration of the shells (e.g., Wadleigh and Veizer 1992; Grossman 1994; Azmy et al. 1998). As a result, the $\delta^{18} \mathrm{O}$ of preserved shells may reflect changes in seawater isotope composition (Veizer et al. 1999), seawater temperature (Azmy et al. 1998), or potential pH (Usdowski and Hoefs 1993; Spero et al. 1997; Zeebe and Wolf-Gladrow 2001). Freshwater from riverine input might influence the brachiopod $\delta^{18} \mathrm{O}$ signature, but the general abundance of corals (mostly stenohaline) with the studied brachiopod assemblages of Anticosti shelf would argue against the significance of the issue. Considering the short time span of the investigated brachiopod populations, the $\delta^{18} \mathrm{O}$ and $\mathrm{pH}$ of ambient seawater can be considered uniform. In contrast, on a marine shelf with a thermocline, seawater temperature should vary with the water depth at which brachiopods lived. In this study, oxygen isotopic signatures of brachiopod shells from the Jupiter Formation of Anticosti Island, Quebec, are examined in an attempt to test the hypothesis that the Early Silurian brachiopod communities lived at characteristic water depths.

\section{Methods}

Brachiopods, mainly pentamerids, were collected from localities of undisturbed, flat-lying Lower Silurian sequences on Anticosti Island, Quebec (cf. Azmy 1996). Each group (A1391b, A1356a, A1380b, A551, A958, and A1030) of samples was mainly gathered from the same individual bed, with shells preserved in life position or in situ (for details see Jin and Copper 2000). These beds were selected to be correlated with global warm episodes (cf. Azmy et al. 1998). Selection of samples and their analysis were performed following the procedures described in Azmy et al. (1998), and only those shells that passed screening for pristine preservation were selected for this study. The shells were cut, usually through the umbo, into slabs. The slabs were gently polished, thin sectioned, and studied under a polarizing microscope and luminoscope (Technosyn cold cathode luminoscope) to evaluate the preservation of shell calcite crystals. Identical sets of slabs were used for microsampling, with carbonate material from the non-luminescent portions of the fibrous layer broken from the shell under a binocular microscope. The fragments were picked by forceps, cleaned in an ultrasonic bath, coated with gold, and examined using a scanning electron microscope (JEOL 6400). The rest of the sample was pulverized.

About $3 \mathrm{mg}$ of the powdered sample was reacted under vacuum overnight with $\sim 0.8 \mathrm{~mL}$ of ultrapure orthophosphoric acid at $25{ }^{\circ} \mathrm{C}$ in a water bath. The resultant $\mathrm{CO}_{2}$ was analyzed using the VG Isogas SIRA-12 triple collecting mass spectrometer at the Hatch Isotope Laboratories of the University of Ottawa. The results are reported in \%o relative to (Vienna Peedee Belemnite, VPDB). The laboratory standards were NBS-18 $\left(\delta^{18} \mathrm{O}=-23.00 \%\right.$ and $\delta^{13} \mathrm{C}=-5.00 \%$ (PDB)) and NBS-19 $\left(\delta^{18} \mathrm{O}=-2.20 \%\right.$ and $\delta^{13} \mathrm{C}=+1.95 \%$ PDB $)$. The routine precision $(2 \sigma)$ for $\delta^{18} \mathrm{O}$ and for $\delta^{13} \mathrm{C}$ was \pm $0.1 \%$. The residual $\mathrm{H}_{3} \mathrm{PO}_{4}$ left after the isotope procedure was analyzed for $\mathrm{Ca}, \mathrm{Mg}, \mathrm{Sr}$, and $\mathrm{Mn}$ (Coleman et al. 1989) using a Hewlett Packard 4500 Series 100 inductively coupled plasma - source spectrometer at the University of Ottawa, Ottawa, Ontario. Blank measurements showed no significant
Fig. 1. Photomicrograph of a thin section of well-preserved shell of Pentamerus sp. (sample 1391b-06). (a) Calcite (arrow) has undeformed prismatic structure, and (b) the same prismatic layer exhibits non-luminescence, in contrast to the brightly luminescent internal sediment.
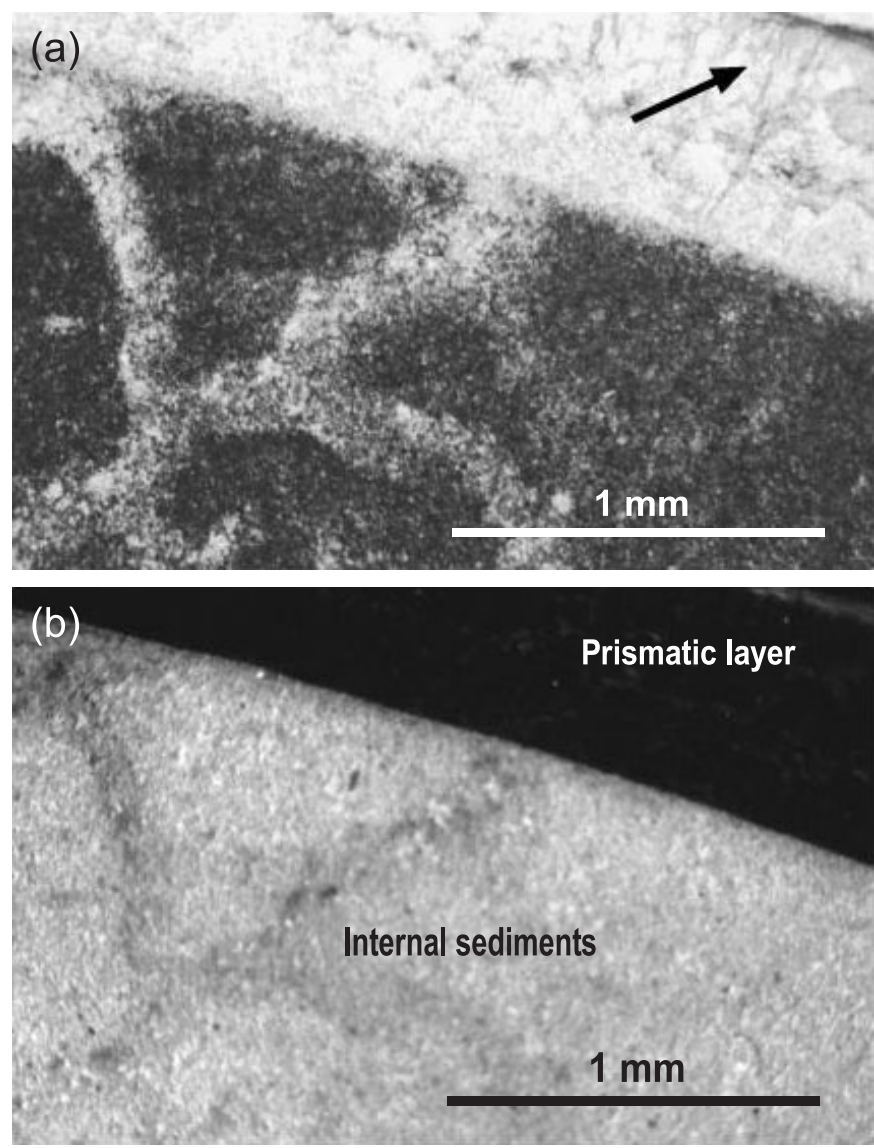

traces of the analyzed major and minor elements. The chemical data were recalculated on an insoluble residue-free basis (100\% soluble carbonate). The analytical precision and accuracy, in relative percent, are 0.4 and 0.3 for $\mathrm{Ca}, 6$ and 8 for $\mathrm{Mg}, 7$ and 9 for $\mathrm{Mn}$, and 4 and 7 for $\mathrm{Sr}$.

\section{Degree of preservation}

\section{Petrographic criteria}

In modern articulate brachiopods, three shell layers can be distinguished: an outer organic periostracum; a middle, few microns thick, granular calcitic primary layer; and an inner secondary layer that is composed of fibrous calcite. The fibrous layer is assumed to have been normally secreted as low-Mg calcite in isotopic equilibrium with ambient seawater (Lowenstam 1961; Carpenter and Lohmann 1995; James et al. 1997; Brand et al. 2003). In fossil brachiopods, the outermost layer (periostracum) is usually absent because of organic decay during fossilization. The primary layer can be seen in well-preserved shells but may easily peel off when the shells are separated from their host rock. Pentamerid brachiopods usually have a thin secondary layer and an additional thicker tertiary prismatic layer (McKinnon 1974). In this study, the thick prismatic layer was used for isotopic analysis and several techniques (optical microscope, cathodoluminescence, SEM, 

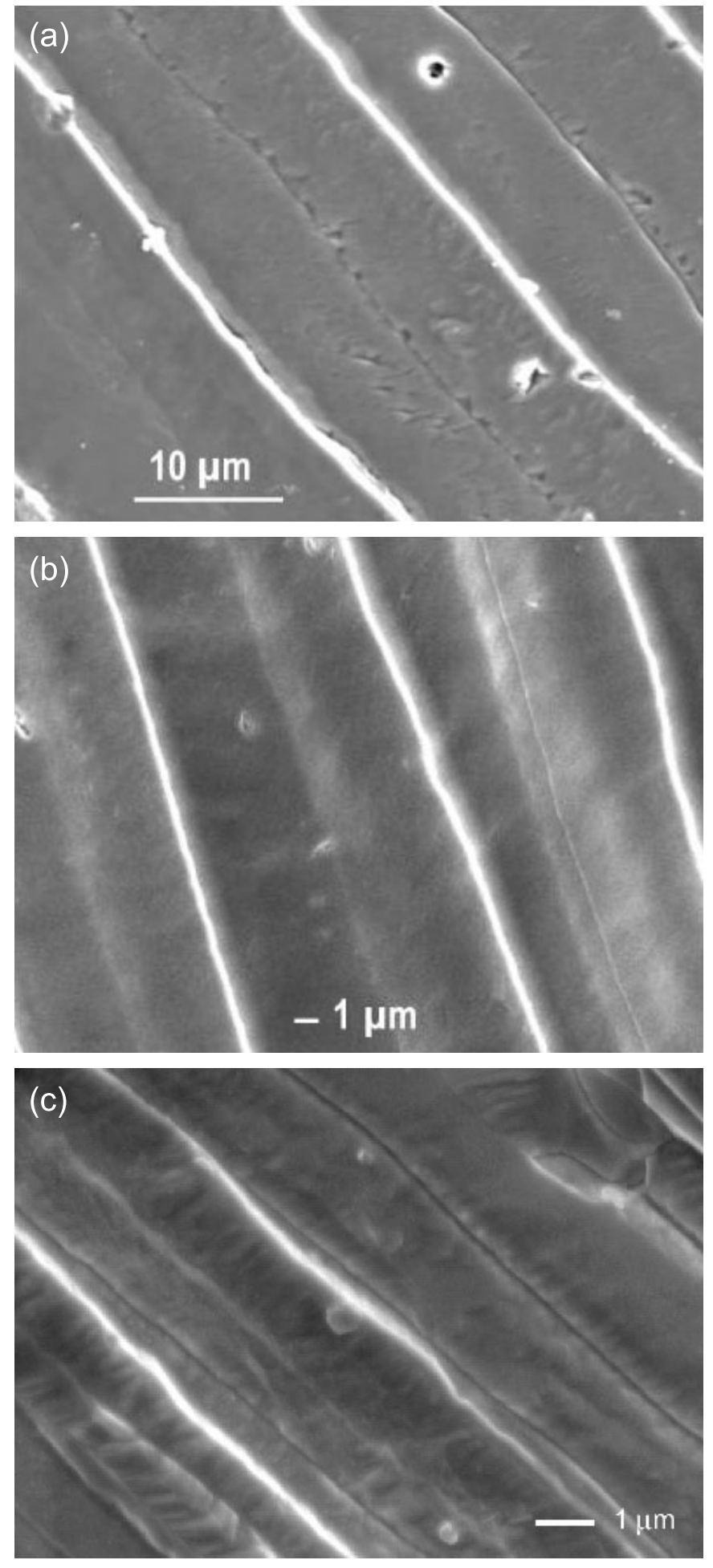

and trace-element analysis) were used to evaluate the pristine nature of the layer (Azmy et al. 1998).

The analyzed material in this study was extracted from the well preserved, non-luminescent prismatic layer (Figs. 1a, 1b). In the pentamerids studied, the secondary layer was very thin and its outer surfaces commonly show diagenetic alteration (cf. Gauri and Boucot 1968). The altered material was removed as much as possible. The pristine preservation of the analyzed portion of the shells is demonstrated by their
Fig. 2. Scanning electron microscopy photomicrographs of the tertiary shell layer of pentamerid brachiopods used for isotopic analysis. (a) Stricklandia planirostrata (Sample A55-01), with very good preservation and clean crystal boundaries. The sample has the following geochemical attributes: Sr $1375 \mathrm{ppm}, \mathrm{Mn}<16 \mathrm{ppm}$, $\mathrm{Mg} 0.10 \%$, Ca $39.86 \%, \delta^{18} \mathrm{O}-6.3 \%$ 。PDB, $\delta^{13} \mathrm{C}-0.6 \%$ V VPDB. (b) Stricklandia planirostrata (Sample A1391b-51), showing excellent preservation and clean crystal boundaries. The sample has the following geochemical attributes: Sr 1378 ppm, Mn < 16 ppm, $\mathrm{Mg} 0.25 \%$, Ca $39.65 \%, \delta^{18} \mathrm{O}-5.2 \%$, $\delta^{13} \mathrm{C} 0.4 \%$. (c) Triplesia anticostiensis (Sample A1030-01), showing very good preservation of ultrastructure. The sample has the following geochemical attributes: $\delta^{18} \mathrm{O}-4.8 \%$ o, $\delta^{13} \mathrm{C} 1.9 \%$.

SEM images, which show stacked calcite prisms with smooth clean boundaries (Azmy et al. 1998; Fig. 2).

\section{Chemical criteria}

The $\delta^{18} \mathrm{O}$ and $\delta^{13} \mathrm{C}$ values (Appendix A, Table A1) for all studied pentamerid and Triplesia shells (97 samples) range from $-3.7 \%$ o to $-5.6 \%$ and from $-2.1 \%$ to $-0.9 \%$ (VPDB), respectively (Fig. 3). This fits well with the range of isotopic compositions of Early Silurian brachiopods studied previously by Azmy et al. (1998). The individual populations show no significant correlation between $\delta^{18} \mathrm{O}$ and $\delta^{13} \mathrm{C}$, with $R^{2}$ values between 0.03 and 0.16 . Note also that there is no correlation between $\delta^{18} \mathrm{O}$ and $\mathrm{Mn}$ or Sr (Figs. $4 a, 4 b$ ). Their $\mathrm{Sr}$ and $\mathrm{Mn}$ contents (Fig. 5) are within the range in modern living brachiopod shells. These observations support the results of petrographic examination (pristine ultrastructure, cathodoluminescence, and SEM images) that indicated a high degree of preservation of original shells (Azmy et al. 1998).

\section{Results and discussion}

Unlike modern brachiopods that are most common in deep and cool marine waters, their Paleozoic counterparts were more abundant and diverse in tropical to subtropical marine shelf environments (Morrison and Brand 1986; Clarkson 1993; Brand et al. 2003; Brand 2004). In the paleogeographic reconstruction of Cocks and Scotese (1991), the Anticosti Basin was located in the tropical zone south of the Silurian equator. At constant $\delta^{18} \mathrm{O}$ and $\mathrm{pH}$ of ambient seawater, the $\delta^{18} \mathrm{O}$ of well preserved brachiopod shells is a reflection of the temperature gradient along the depth profile of the water column. Isotope fractionation by vital effect for brachiopods has neither been conclusively demonstrated nor discounted in fossil shells (e.g., Grossman 1994; Azmy et al. 1998) or their modern counterparts, but it was noticed only in few species that precipitate their shell in isotopic disequilibrium with ambient seawater (e.g., Auclair et al. 2003; Brand et al. 2003). Vital effects do not appear to have been of significance particularly for Silurian (Azmy 1996) and Devonian (Lee and Wan 2000) brachiopods. During the Early Silurian, three global glacial episodes were marked by positive $\delta^{18} \mathrm{O}$ shifts (Fig. 6) in the isotope profile of the Anticosti sequence (Azmy et al. 1998; Veizer et al. 1999). In testing the hypothesis of paleobathymetric (or paleotemperature) gradient, closely related brachiopod genera with similar paleoecological niches (Pentamerus, Stricklandia, Ehlersella, and Triplesia) were 
Fig. 3. Oxygen vs. carbon isotope values for all studied Silurian brachiopods. Sample populations as in Table 1.

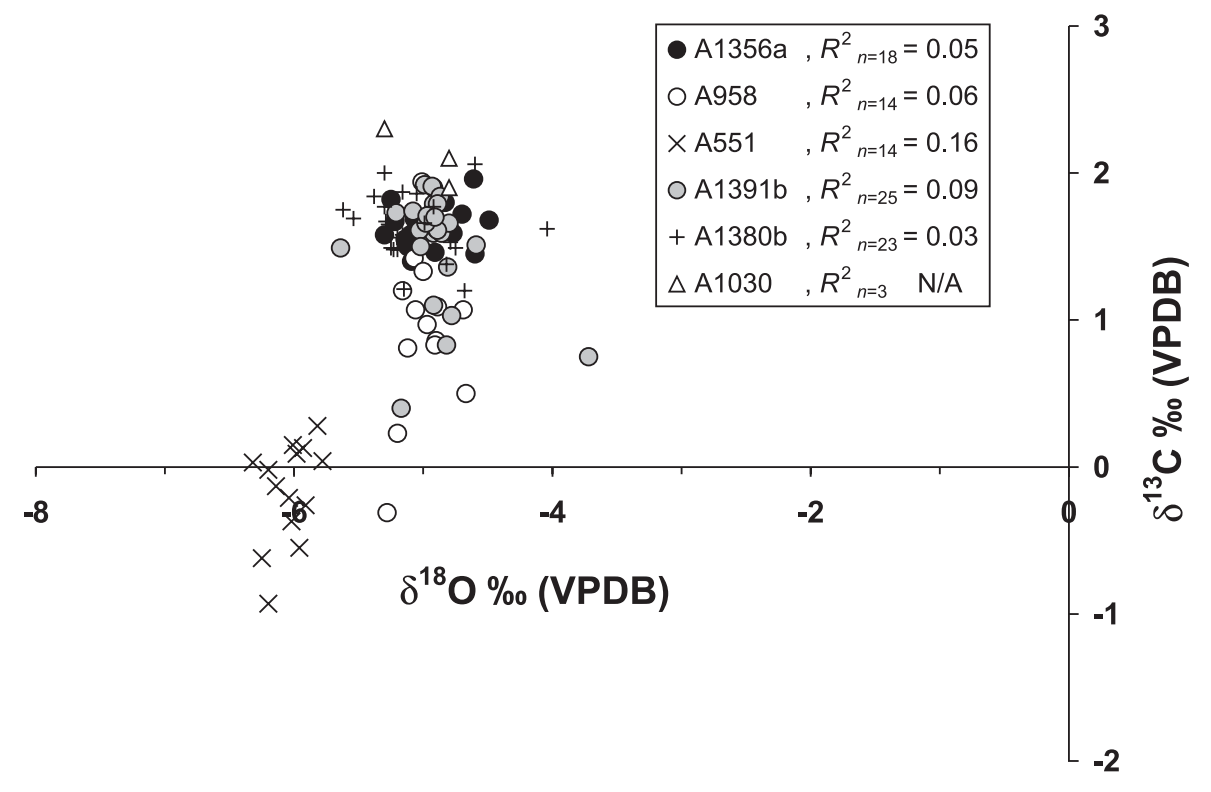

selected for study. Brachiopod samples from different water depths can be acquired either along a ramp at the same time plane or from different time planes in the same stratigraphic succession accumulated during fluctuating sea levels. Because the nature of outcrops in Anticosti does not allow collecting brachiopod assemblages from a single stratigraphic level spanning shallow intertidal to relatively deeper outer shelf settings, samples of this study were obtained from beds representing different depths but all of these beds are believed to have been deposited during warm high sea-level conditions (Fig. 6) to avoid the influence of glacial events that occurred during Early Silurian (see Azmy et al. 1998 for details on sea-level changes and glacial events). Communities dominated separately by Pentamerus, Stricklandia, Ehlersella, or Triplesia (Clorinda habitat counterparts) are interpreted to have occupied different water depths (Table 1) during the Early Silurian (see Jin and Copper 2000 for detailed discussion on these brachiopod communities and depths of their habitat). Shells of these genera from several levels of the same Anticosti succession, which are believed to represent different depths during the interglacial episodes, are used for isotopic analysis (Fig. 6).

Accepting the validity of the brachiopod-dominated BA scheme of Brett et al. (1993), and assuming that the normal storm wave base at Anticosti was about $30 \mathrm{~m}$ (Jin and Copper 1999), the Pentamerus oblongus Community from locality A1356a may be assigned to BA3 with an estimated depth range of $20-40 \mathrm{~m}$, whereas the Pentamerus palaformis Community from localities $1380 \mathrm{~b}$ and A1391b, as well as the stricklandiid communities A958 and A551, may be assigned to BA4 with an estimated depth range of 60-90 m (Table 1). The Triplesia Community represents the relatively deepest habitat similar to that of Clorinda and may be assigned to BA5, with estimated depth $\geq 90 \mathrm{~m}$. Considering an $\sim 70 \mathrm{~m}$ difference in average water depth between the BA3 and BA5 communities, water temperature is expected to decrease with depth, and brachiopod shells should become relatively more enriched in ${ }^{18} \mathrm{O}$.
The average annual vertical temperature gradient for the upper $100 \mathrm{~m}$ in analogous modern tropical shelf environments varies between $2{ }^{\circ} \mathrm{C} / 100 \mathrm{~m}$ at the Bahamas $\left(23^{\circ} 47^{\prime} 46^{\prime} \mathrm{N}\right.$, $76^{\circ} 05^{\prime} 85^{\prime \prime} \mathrm{W}$ ) and the Java Sea and $10{ }^{\circ} \mathrm{C} / 100 \mathrm{~m}$ in upwelling regions on the western coasts of continents (Sverdrup et al. 1942; Tomascik and Mah 1997). Most tropical shelf environments have homogeneous temperatures in the well mixed uppermost $20 \mathrm{~m}$ of the water column. For $T^{\circ} \mathrm{C} /{ }^{18} \mathrm{O}$ gradient of $\sim 5{ }^{\circ} \mathrm{C} / 1 \%$ o (e.g., Hays and Grossman 1991), the associated $\delta^{18} \mathrm{O} /$ depth gradient is, therefore, about $0.5 \% 0-2 \%$ per $100 \mathrm{~m}$. With such gradients, the $70 \mathrm{~m}$ depth step should lead to about $0.5 \%$ - $1.5 \%$ difference in the average $\delta^{18} \mathrm{O}$ values of the BA3 and BA5 communities. The isotopic signatures of the analyzed brachiopod shells, however, show that this is not the case. The mean values (and their variances) are practically identical for all samples (Tables 1,2), except for the Stricklandia Community from locality A551. Furthermore, within the resolution of a biozone, the mean values for the pentamerid communities from localities A1356a, A1391b, and A1380b are identical to those of the previously studied populations (refer to the $t$-test, Table 2) by Azmy et al. (1998). The agreement for the Ehlersella Community from locality A958 is at $<95 \%$ probability level, but this is possibly a reflection of its small sample size and not of different $\delta^{18} \mathrm{O}$ values. Consequently, either the temperature-depth gradient at Anticosti shelf during the Early Silurian was less than that of the present Bahamas (Sverdrup et al. 1942), with $\delta^{18} \mathrm{O}$ variability almost within the range of intra-shell variations (Carpenter and Lohmann 1995; Azmy 1996), or the proposed depth ranges for the BA communities represent an overestimate particularly for carbonate shelf environments. In any case, the $\delta^{18} \mathrm{O}$ technique does not seem to have sufficient sensitivity for testing of ecological parameters at this resolution based on this study.

The mean $\delta^{18} \mathrm{O}$ value of the Stricklandia planirostrata Community (BA4) is clearly outside the range of the studied communities, as well as the contemporaneous samples from the earlier study of Azmy et al. (1998; Fig. 6). Taking into 
Fig. 4. Scatter diagram of $\delta^{18} \mathrm{O}$ vs. $(a) \mathrm{Mn}$ and $(b) \mathrm{Sr}$ for brachiopod shells. No diagenetic trends are evident. Sample populations as in Table 1.
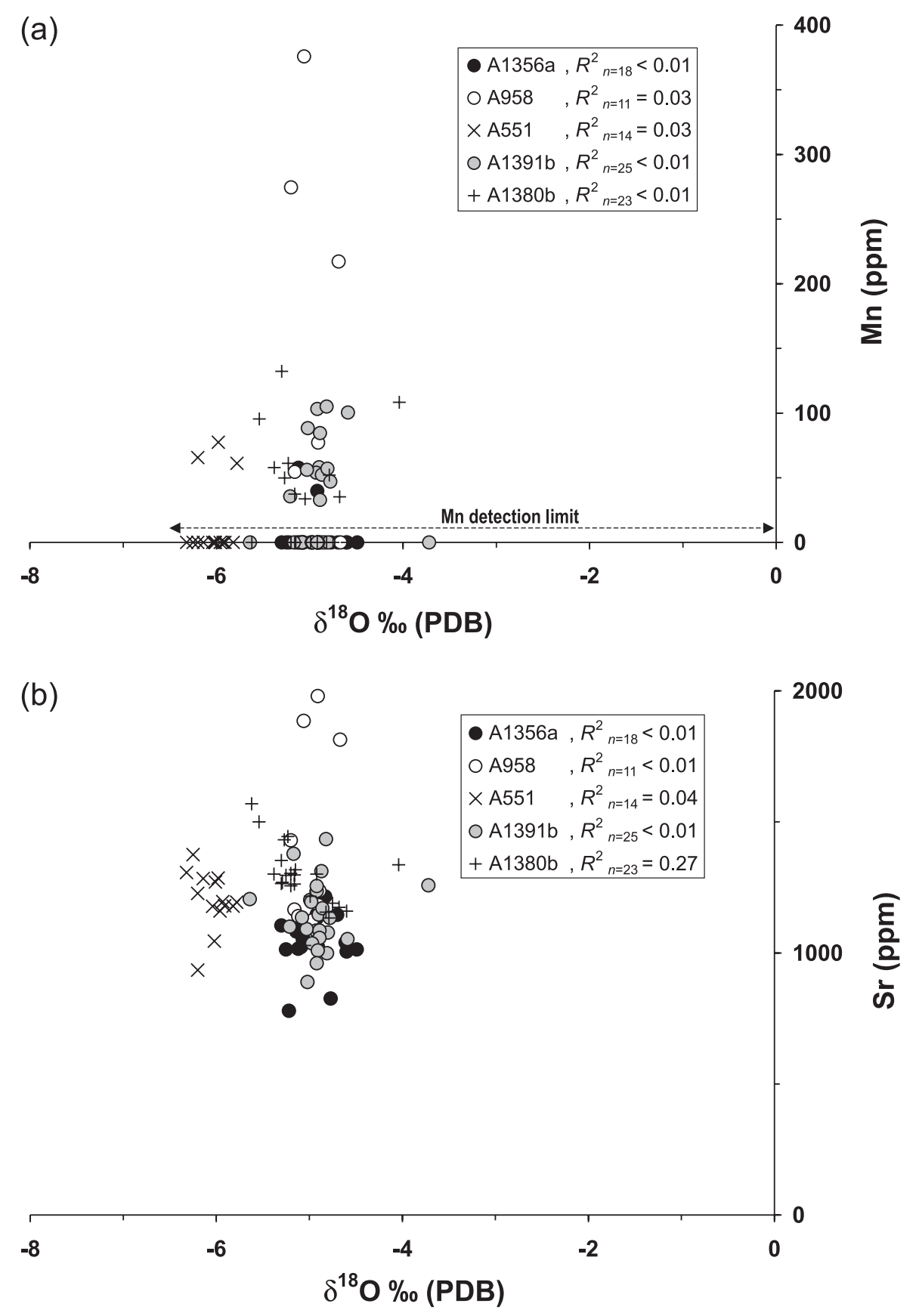

consideration that the brachiopod assemblages, associated with corals, were most likely stenohaline and stenothermal populations (Long and Copper 1994), the $\sim 1 \%{ }^{18} \mathrm{O}$ depletion shown by the Stricklandia shells from locality A551 would mean that the water inhabited by the Stricklandia planirostrata population was $5{ }^{\circ} \mathrm{C}$ warmer (hence much shallower) than that inhabited by the other pentamerid populations studied. Diagenetic alteration is not likely a cause for the ${ }^{18} \mathrm{O}$ depletion in the Stricklandia shells because SEM images of microscopic shell structures (Fig. 2) and trace-element analysis (Fig. 4) point to the pristine preservation of the shells (e.g., Azmy et al. 1998). Shells of Stricklandia planirostrata popu- lations preserved in life position show much more common anterior truncations by storm-generated turbidity flows than most Pentamerus palaformis and Ehlersella davidsonii populations (Jin and Copper 2000). This appears to agree with the stable isotope data, indicating that the Stricklandia planirostrata Community lived in warmer, shallower water settings than the other pentamerid communities analyzed in this study.

The $\delta^{13} \mathrm{C}$ values of brachiopods do not generally show consistent variation with depth either in fossil (e.g., Grossman et al. 1991) or in recent shells (Brand et al. 2003). In modern deep seas, preferential removal of ${ }^{12} \mathrm{C}$ by photosynthesis causes ${ }^{13} \mathrm{C}$ enrichment in surface water, whereas oxidation 
Fig. 5. Scatter diagram of Mn vs. Sr for brachiopod shells. The box represents the trace-element ranges for Recent brachiopods based on the data of Lowenstam (1961), Dittmar and Vogel (1968), Frank et al. (1982), Lepzelter et al. (1983), Grossman (1994), and Brand et al. (2003). Sample populations as in Table 1.

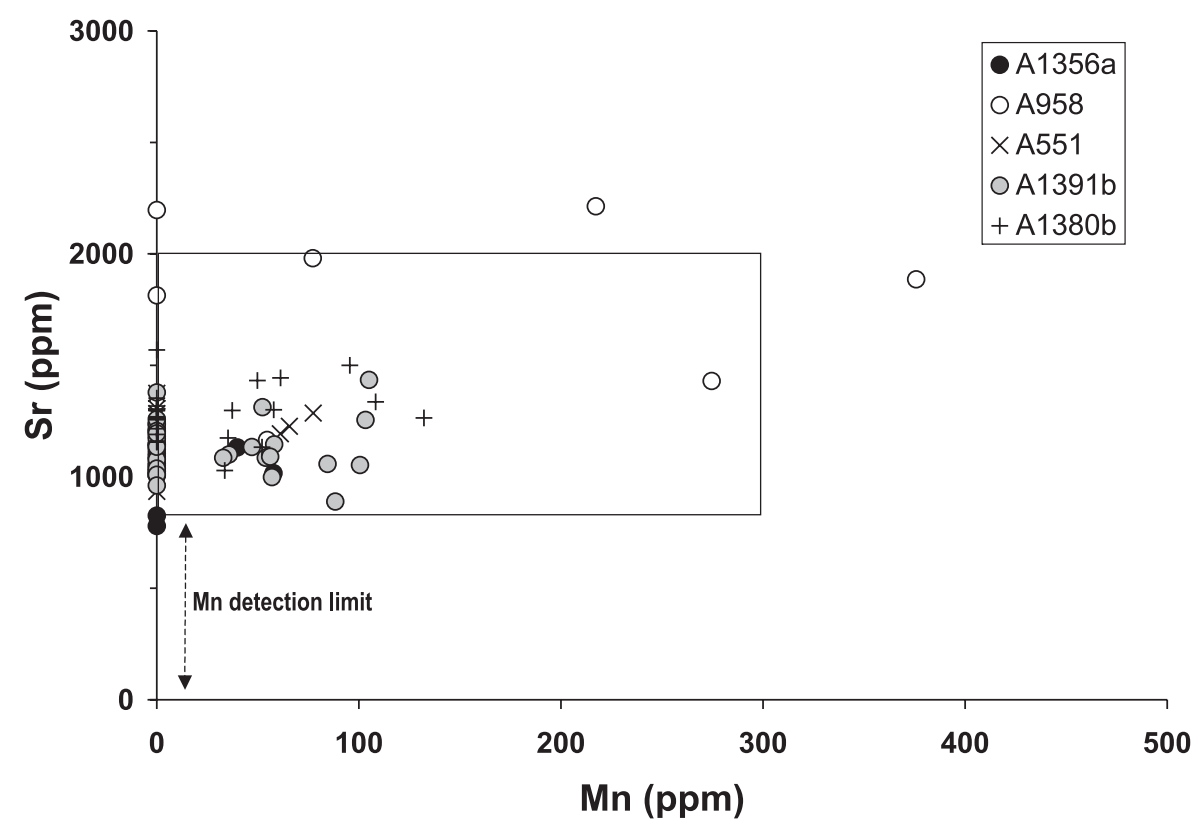

Fig. 6. A simplified stratigraphic log for the Anticosti succession with global $\delta^{18} \mathrm{O}$ (Azmy et al. 1998) and sea-level (Jin and Copper 1999) curves. Dashed lines indicate the stratigraphic positions of the collected samples, stippled bars are the mean $\pm 1 \sigma$ for presently studied communities, and the boxes and circles are the mean $\pm 1 \sigma$ ranges for previously studied populations of brachiopods (Azmy et al. 1998). Numbers 1-14 (on scale at left) are graptolite biozones (see Azmy et al. 1998 for details): ${ }^{1}$ acuminatus, ${ }^{2}$ avatus, ${ }^{4}$ cyphus, ${ }^{5}$ triangulatus, ${ }^{7}$ leptotheca,${ }^{8}$ convolutus, ${ }^{9}$ sedgwickii, ${ }^{10}$ turriculatus, ${ }^{11}$ crispus, ${ }^{13}$ crenulata, ${ }^{14}$ centrifugus. Sample populations as in Table 1.

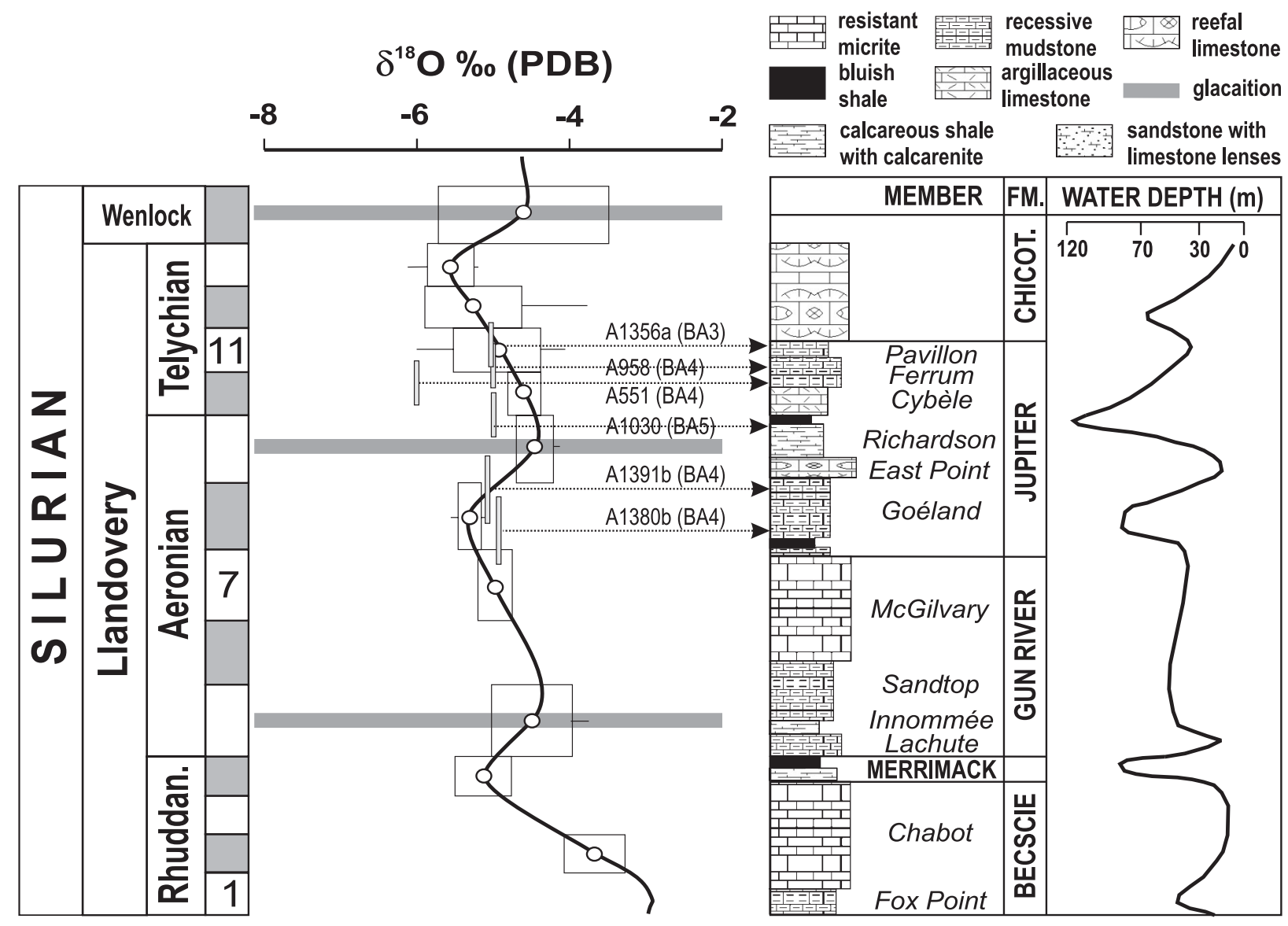


Table 1. Mean $\delta^{18} \mathrm{O}$, host rock lithology, benthic assemblage (BA) assignments, and estimated water depth of the brachiopod communities studied herein.

\begin{tabular}{|c|c|c|c|c|c|c|}
\hline Brachiopod community & Sample locality & $\delta^{18} \mathrm{O} \pm \sigma$ & $\delta^{13} \mathrm{C} \pm \sigma$ & Host rock lithology & BA & Water depth $(\mathrm{m})$ \\
\hline Pentamerus oblongus $(n=18)$ & A1356a & $-4.95 \pm 0.24$ & $1.65 \pm 0.16$ & $\begin{array}{l}\text { packstone to } \\
\text { wackestone }\end{array}$ & BA3 & $20-40$ \\
\hline Ehlersella davidsonii $(n=14)$ & A958 & $-4.98 \pm 0.16$ & $1.02 \pm 0.42$ & mudstone & BA4 & $60-90$ \\
\hline Pentamerus palaformis $n=25$ ) & A1391b & $-4.90 \pm 0.31$ & $1.50 \pm 0.38$ & marly limestone & BA4 & $60-90$ \\
\hline Pentamerus palaformis $(n=23)$ & A1380b & $-5.07 \pm 0.35$ & $1.64 \pm 0.22$ & mudstone & BA4 & $60-90$ \\
\hline
\end{tabular}

Table 2. Mean, standard deviation (StDev), maximum (Max) and minimum (Min) isotope values, and t-test values calculated for the studied brachiopod community.

\begin{tabular}{lcccccr}
\hline & A1356a & A551 & A958 & A1391b & A1380b & A1030 \\
\hline Mean $\delta^{18}$ O VPDB & -5.00 & -6.04 & -5.00 & -4.90 & -5.10 & -4.97 \\
StDev & 0.24 & 0.16 & 0.18 & 0.31 & 0.35 & 0.29 \\
Max & -4.49 & -5.78 & -4.67 & -3.72 & -4.04 & -4.77 \\
Min & -5.30 & -6.32 & -5.28 & -5.64 & -5.62 & -5.33 \\
$n$ & 18 & 14 & 14 & 25 & 23 & 3 \\
$R^{2}$ & 0.05 & 0.16 & 0.06 & 0.09 & 0.03 & NA \\
t-test & 0.31 & 13.97 & 3.58 & 3.17 & 0.36 & NA \\
\hline
\end{tabular}

of organic matter causes ${ }^{13} \mathrm{C}$ depletion in deep water, and the gradient becomes steeper at high latitudes (Brand et al. 2003). However, this is not the case in modern shallow water, an environment similar to that of Anticosti platform, where $\delta^{13} \mathrm{C}$ gradient is almost insignificant (Grossman and $\mathrm{Ku}$ 1986; Brand et al. 2003). This is consistent with the $\delta^{13} \mathrm{C}$ signatures of the studied pentmerids (Table 1) that have very close values falling within the range of modern shallow-water, low-latitude brachiopod shells (cf. Brand et al. 2003) and showing no correlation with depth.

\section{Conclusions}

(1) The petrographic and chemical criteria of the studied pentamerid shells indicate good preservation of original shell material and the retention of primary isotope compositions.

(2) The $\delta^{18} \mathrm{O}$ signals of pentamerid brachiopods of Anticosti Island indicate that the Anticosti shelf had a warm, vertically well mixed water mass from late Aeronian to middle Telychian time during the Early Silurian. Pentamerid brachiopod communities with a water-depth difference of $<70 \mathrm{~m}$ show little differentiation in their $\delta^{18} \mathrm{O}$ values.

(3) Although stricklandiid brachiopods may have been generally believed to occupy a deeper, quieter, and probably cooler water settings than Pentamerus, the Stricklandia planirostrata Community in the carbonate environment in Anticosti Island appears to have lived in warmer, shallower water conditions than Pentamerus palaformis and Ehlersella davidsonii communities, as indicated by taphonomic and stable isotope data. However, sedimentological data indicate that the Pentamerus oblongus Community lived in shallower, more turbulent waters than the stricklandiid communites. This implies that the previous concept of a BA3 Pentamerus Community, which is based largely on $P$. oblongus of other regions, applies also to the $P$. oblongus Community in the uppermost Jupiter Formation of Anticosti Island, but it does not apply to the $P$. palaformis Community in the lower Jupiter Formation.

(4) The $\delta^{18} \mathrm{O}$ signature of Triplesia anticostiensis of Anticosti Basin reflects warmer water conditions or a shallower water environment than that expected for a BA5 setting.

\section{Acknowledgments}

We thank A. Boucot, M. E. Johnson, B. Chatterton, and E. Grossman for their constructive reviews of this manuscript. This project was funded by research grants from the Natural Sciences and Engineering Research Council of Canada (to J. Veizer, J. Jin, and P. Cooper) and the Canadian Institute for Advanced Research (grants from Noranda and G. G. Hatch and Associates to J.Veizer).

\section{References}

Adlis, D.S., Grossman, E.L., Yancey, T.E., and McLerran, R.D. 1988. Isotope stratigraphy and paleodepth changes of Pennsylvanian cyclical sedimentary deposits. Palaios, 3: 487-506.

Auclair, A.C., Joachimski, M.M., and Lécuyer, C. 2003 Deciphering kinetic, metabolic and environmental controls on stable isotope fractionations between seawater and the shell of Terebratalia transversa (Brachiopoda). Chemical Geology, 202: 59-78.

Azmy, K. 1996. Isotopic composition of Silurian brachiopods: implications for coeval seawater. Ph.D. thesis, University of Ottawa, Ottawa, Ont.

Azmy, K., Veizer, J., and Bassett, M.G., and Copper, P. 1998. Oxygen and carbon isotopic composition of Silurian brachiopods: impli- 
cations for coeval seawater and glaciations. Geological Society of America Bulletin, 110: 1499-1512.

Boucot, A.J. 1975. Evolution and extinction rate controls. Elsevier, New York.

Boucot, A.J. 1999. Some Wenlockian-Gedinnian, chiefly brachiopoddominated, communities of North America. In Paleocommunities: a case study from the Silurian and lower Devonian. Edited by A.J. Boucot and J.D. Lawson. Cambridge University Press, Cambridge, UK, pp. 43-591.

Brand, U. 2004. Carbon, oxygen and strontium isotopes in Paleozoic carbonate components: an evaluation of original seawater-chemistry proxies. Chemical Geology, 204: 23-44.

Brand, U., Logan, A., Hiller, N., and Richardson, J. 2003. Geochemistry of modern brachiopods: applications and implications for oceanography and paleoceanography. Chemical Geology, 198: 305-334.

Brett, C.E., Boucot, A.J., and Jones, B. 1993. Absolute depths of Silurian benthic assemblages. Lethaia, 26: 25-41.

Carpenter, S.J., and Lohmann, K.C. 1995. $\delta^{18} \mathrm{O}$ and $\delta^{13} \mathrm{C}$ values of modern brachiopods. Geochimica et Cosmochimica Acta, 59: 3749-3764.

Clarkson, E.N.K. 1993. Invertebrate paleontology and evolution. Chapman and Hall, London.

Cocks, L.R.M., and Scotese, C.R. 1991. The global biogeography of the Silurian Period. Palaeontology, Special Paper 44, pp. 109-122.

Coleman, M.L., Walsh, J.N., and Benmore, R.A. 1989. Determination of both chemical and stable isotope composition in milligramsize carbonate samples. Sedimentary Geology, 65: 233-238.

Dittmar, H., and Vogel, K. 1968. Die Superenelemente Mangan und Vanadium in Brachiopoden-Schalen in Abhängigkeit vom Biotop. Chemical Geology, 3: 95-110.

Frank, J.R., Carpenter, A.B., and Oglesby, T.W. 1982. Cathodoluminescence and composition of calcite cement in the Taum Sauk Limestone (Upper Cambrian), southeast Missouri. Journal of Sedimentary Petrology, 52: 631-638.

Gauri, K.L., and Boucot, A.J. 1968. Shell structure and classification of Pentameracea M'Coy, 1844. Palaeontographica, Abteilung A: Palaeozoologie-Stratigraphie, 131: 79-127.

Grossman, E.L. 1994. The carbon and oxygen isotope record during the evolution of Pangea: Carboniferous to Triassic. In Geological Society of America, Special Paper 288, pp 207-228.

Grossman, E.L., and Ku, T.-L. 1986. Oxygen and carbon isotope fractionation in biogenic aragonite; temperature effects. Chemical Geology, 59: 59-74.

Grossman, E.L., Zhang, C., and Yancey, T.E. 1991. Stable isotope stratigraphy from brachiopods in Pennsylvanian (Upper Carboniferous) shales of Texas. Geological Society of America Bulletin, 103: 953-965.

Hays, P.D., and Grossman, E.L. 1991. Oxygen isotopes in meteoric calcite cements as indicators of continental paleoclimate. Geology, 19: 441-444.

James, N.P., Bone, Y., and Kyser, T.K. 1997. Brachiopod $\delta^{18} \mathrm{O}$ values do reflect ambient oceanography: Lacepede Shelf, southern Australia. Geology, 25: 551-554.

Jin, J. 2003. The Early Silurian brachiopod Eocoelia from the Hudson Bay Basin, Canada. Palaeontology, 46: 1-18.

Jin, J. 2005. Reef-dwelling gypiduloid pentameride brachiopods in the Lower Silurian (upper Telychian) Attawapiskat Formation, Hudson Bay region, Canada. Journal of Paleontology, 79: 48-62.

Jin, J., and Copper, P. 1999. The deep-water brachiopod Dicoelosia king, 1950, from the early Silurian tropical carbonate shelf of Anticosti Island, eastern Canada. Journal of Paleontology, 73: 1042-1055.

Jin, J., and Copper, P. 2000. Late Ordovician and Early Silurian pentamerid brachiopods of Anticosti Island, Québec, Canada. Palaeontographica Canadiana, No. 18.

Jin, J., Caldwell, W.G.E., and Norford, B.S. 1993. Early Silurian brachiopods and biostratigraphy of the Hudson Bay Lowlands, Manitoba, Ontario, and Quebec. Geological Survey of Canada, Bulletin 457.

Johnson, M.E. 1987. Extent and bathymetry of North American Platform seas in the Early Silurian. Paleoceanography, 2: 185-211.

Johnson, M.E. 1989. Tempestites recorded as variable Pentamerus layers in the Lower Silurian of southern Norway. Journal of Paleontology, 63: 195-205.

Johnson, M.E., and Campbell, G.T. 1980. Recurrent carbonate environments in the Lower Silurian of northern Michigan and their inter-regional correlation. Journal of Paleontology, 54: 1041-1057.

Johnson, M.E., Cocks, L.R.M., and Copper, P. 1981. Late Ordovician Early Silurian fluctuations in sea level from eastern Anticosti Island, Quebec. Lethaia, 14: 72-82.

Johnson, M.E., Rong Jia-yu, and Yang Xuechang 1985. Intercontinental correlation by sea level events in the Early Silurian of North America and China (Yantze Platform). Geological Society of America Bulletin, 96: 1384-1397.

Landing, E., and Johnson, M.E. (Editors). 1998. Silurian cycles of dynamic stratigraphy with atmospheric, oceanic, and tectonic changes. New York State Museum Bulletin 491.

Lee, X., and Wan, G. 2000. No vital effect on $\delta^{18} \mathrm{O}$ and $\delta^{13} \mathrm{C}$ values of fossil brachiopod shells, Middle Devonian of China. Geochimica et Cosmochimica Acta, 64: 2649-2664.

Lepzeltzer, C.G, Anderson, T.F., and Sandberg, P.A. 1983. Stable isotope variation in modern articulate brachiopods. In American Association of Petroleum Geologists, Abstract 67(3): 500-501.

Long, D.G.F., and Copper, P. 1994. The Late Ordovician-Early Silurian carbonate tract of Anticosti Island, Gulf of St. Lawrence, eastern Canada. Geological Association of Canada - Mineralogical Association of Canada, Joint Annual General Meeting 1994, Waterloo, Ont. Field Trip Guidebook B4.

Lowenstam, H.A. 1961. Mineralogy, ${ }^{18} \mathrm{O} /{ }^{13} \mathrm{C}$ ratios, and strontium and magnesium contents of recent and fossil brachiopods and their bearing on the history of oceans. Journal of Geology, 69: 241-260.

McKerrow, W.S. 1979. Ordovician and Silurian changes in sea level. Journal of Geological Society (of London), 136: 137-145.

McKinnon, D.I. 1974. The shell structure of spiriferid Brachiopoda. Bulletin of British Museum, 25: 187-261.

Morrison, O.J., and Brand, U. 1986. Paleocene No. 5: Geochemistry of recent marine invertebrates. Geoscience Canada, 13: 237-254.

Railsback, L.B., Akerly, S.P., Anderson, T.F., and Cisne, J.L. 1990, Paleontological and isotope evidence for warm saline deep waters in Ordovician oceans. Nature (London), 343: 156-159.

Spero, H.J., Bijma, D.W.L., and Bemis, B.E. 1997. Effect of seawater carbonate concentration on foraminiferal carbon and oxygen isotopes. Nature (London), 390: 497-500.

Sverdrup, H.U., Johnson, M.W., and Fleming, R.H. 1942. The Oceans, their physics, chemistry, and general biology. PrinceHall, Inc., Englewood Cliff, N.J.

Tomascik, T., and Mah, A.J. 1997. The ecology of the Indonesian seas. In The ecology of Indonesia series. Vol. 7. Periplus, Singapore p. 642 .

Usdowski, E., and Hoefs, J. 1993. Oxygen isotope exchange between carbonic acid, bicarbonate, carbonate, and water: a re-examination of the data of McCrea (1950) and an expression for an overall partitioning of oxygen isotopes between the carbonate species and water. Geochimica et Cosmochimica Acta, 57: $3815-3818$. 
Veizer, J., Ala, D., Azmy, K., Bruckschen, P., Bruhn, F., Buhl, D., et al. ${ }^{1999 .}{ }^{87} \mathrm{Sr} /{ }^{86} \mathrm{Sr}, \delta^{18} \mathrm{O}$ and $\delta^{13} \mathrm{C}$ evolution of Phanerozoic seawater. Chemical Geology, 161: 59-88.

Wadleigh, M.A., and Veizer, J. 1992. ${ }^{18} \mathrm{O} /{ }^{16} \mathrm{O}$ and ${ }^{13} \mathrm{C} /{ }^{12} \mathrm{C}$ in Lower Paleozoic articulate brachiopods: implications for the isotopic composition of seawater. Geochimica et Cosmochimica Acta, 56: 431-443.

Williams, D.F., Lerche, I., and Full, W.E. 1988. Isotope chronostratigraphy: theory and methods. Academic Press, New York, N.Y.
Zeebe, R.E., and Wolf-Gladrow, D. 2001. $\mathrm{CO}_{2}$ in seawater: Equilibrium, kinetics and isotopes. Elsevier, Amsterdam, The Netherlands.

Ziegler, A.M. 1965. Silurian marine communities and their environmental significance. Nature (London), 207: 270-272.

Ziegler, A.M., Cocks, L.R.M., and Bambach, R.K. 1968. The composition and structure of Lower Silurian communities. Lethaia, 1: 1-27. 


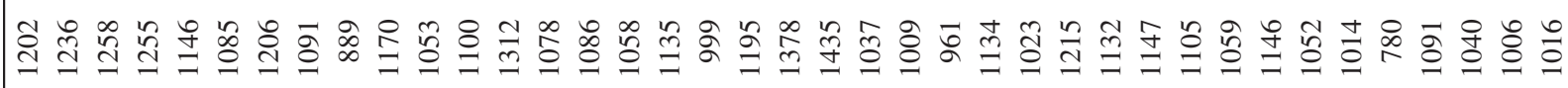

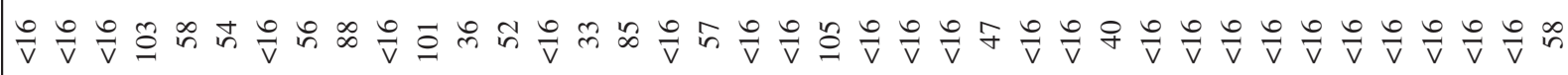

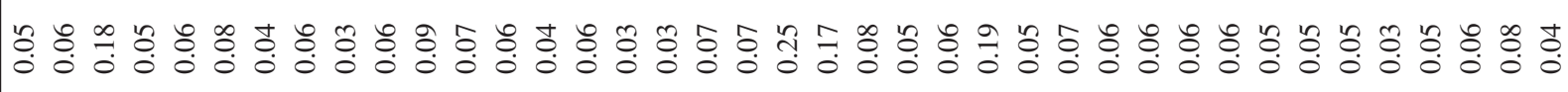

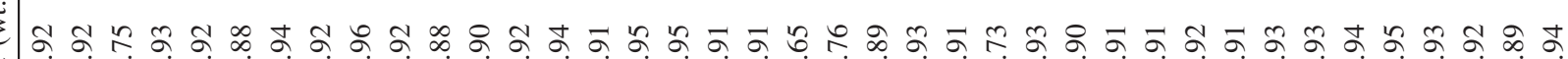

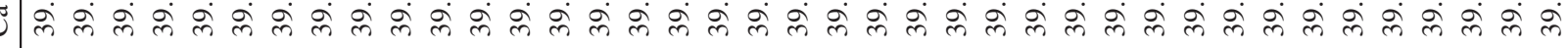

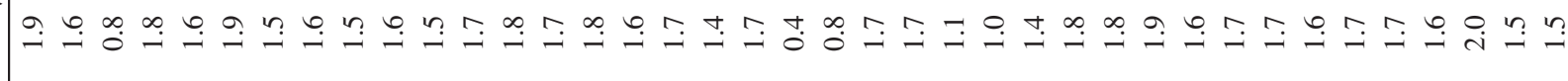

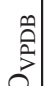

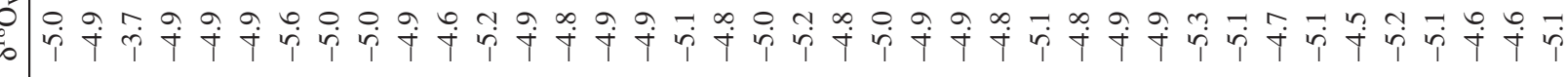

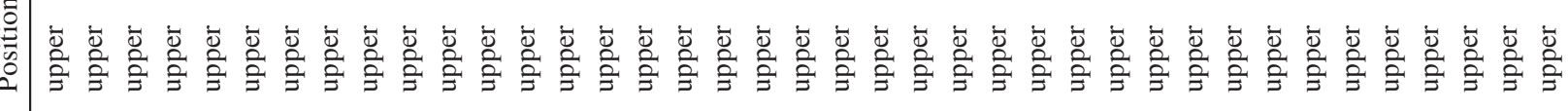

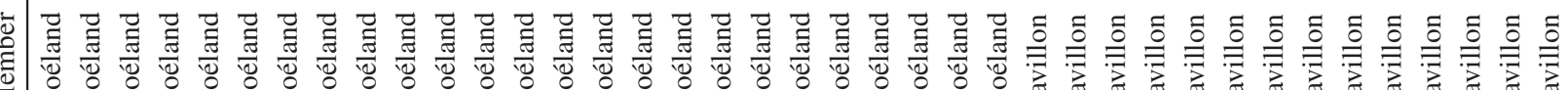

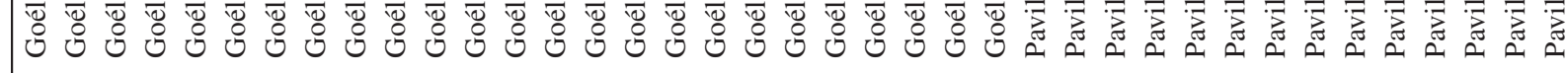

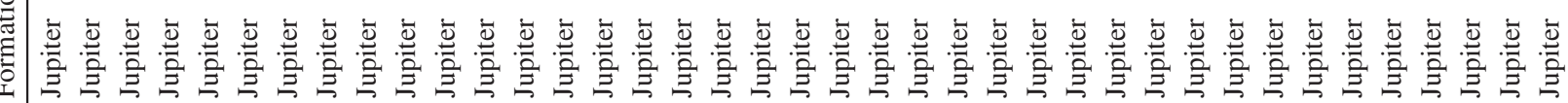

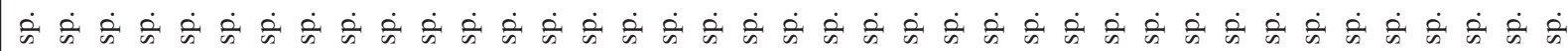

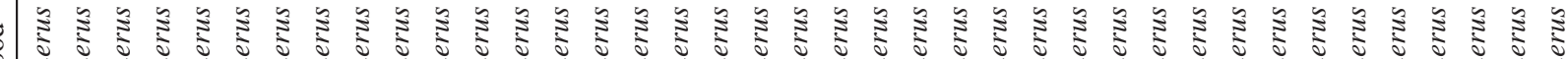

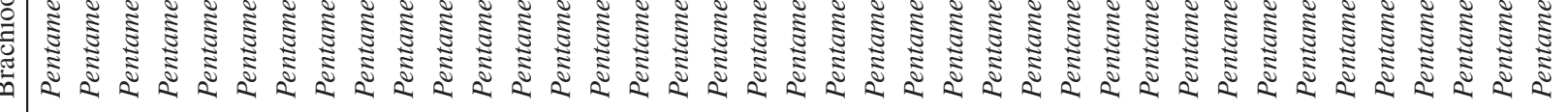

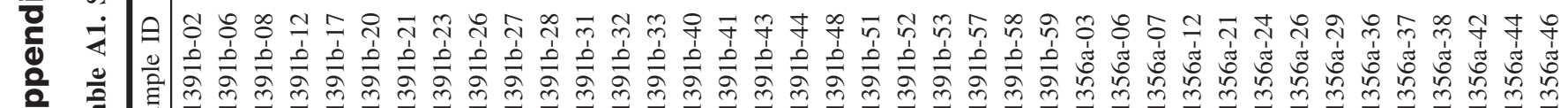

遂 


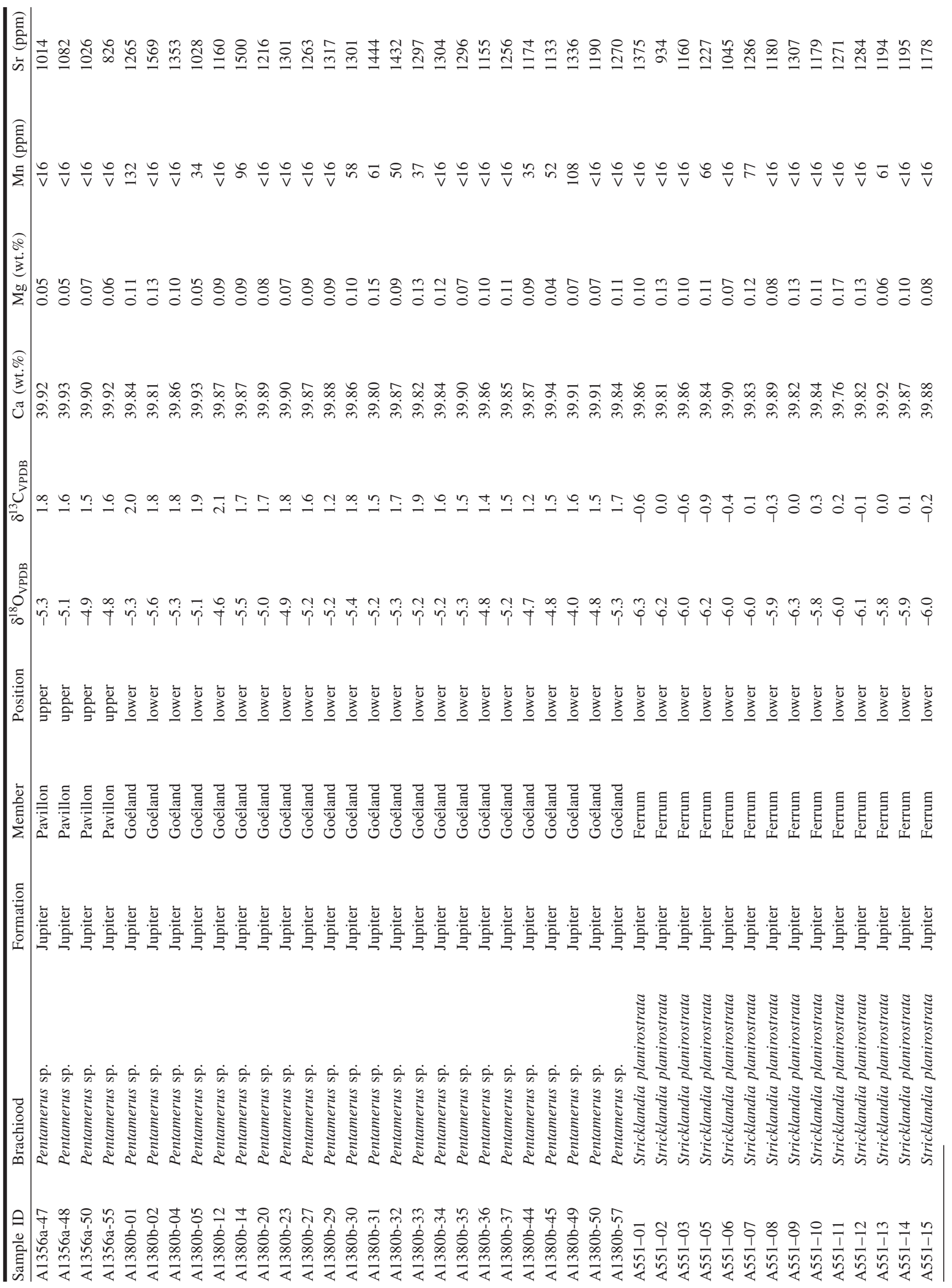




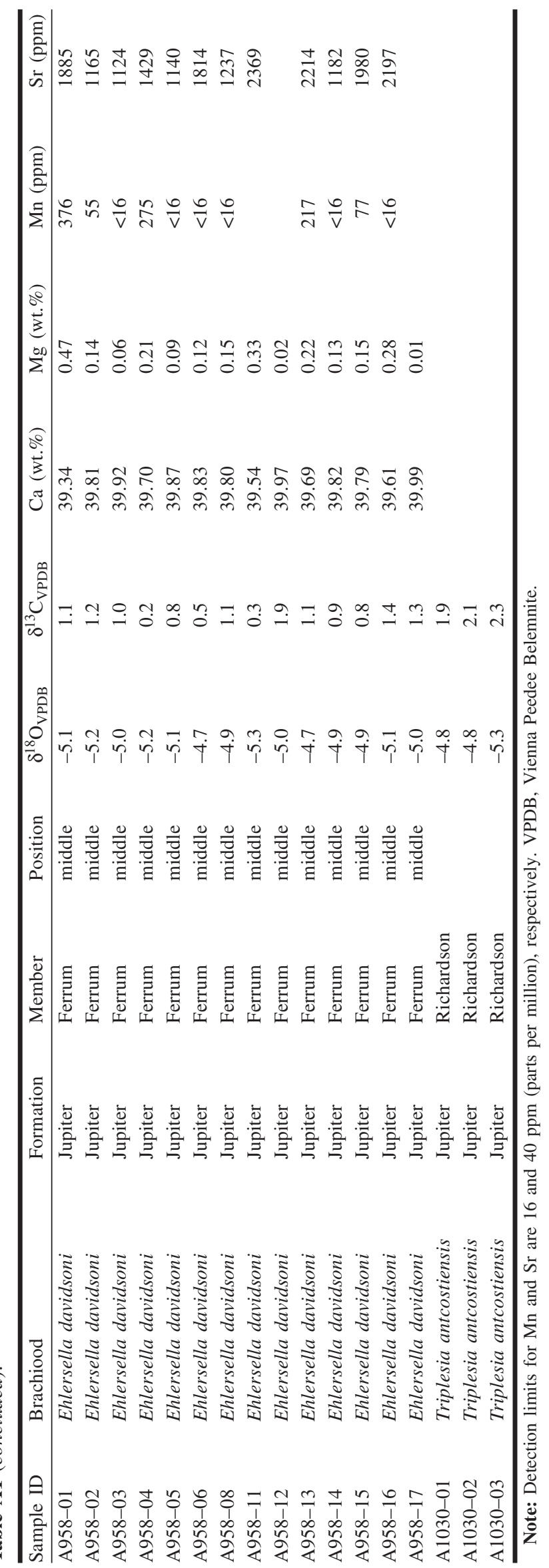

